\title{
Linguistic variation in subtitling for audiovisual media in Portugal: case study of the film Gone with the Wind
}

\author{
Lili Lopes Cavalheiro \\ University of Lisbon
}

Film subtitling involves per se a number of constraints. However, when characters speak with a particular dialect or accent, the task is even more complex. Linguistic variation is a key factor in depicting a film character and the translator will consider the implications of his/her choice when translating into the Target Culture, since such sociolinguistic and/or idiosyncratic language features contribute to the meaning(s) of a film. The presence of linguistic variation may be tied in with the medium through which a film is distributed; hence translating for different media may imply the application of different strategies. This article will analyze the film subtitling of Gone with the Wind (1939), in particular how Mammy's speech is translated into Portuguese for RTP (public television channel), TVI (private television channel), VHS and the Internet, while also searching for translational regularities.

\section{Introduction}

The audiovisual media is essentially determined by its polysemiotic nature, since images and language collaborate to give meaning to the 'text' as a whole. In the particular case of films, the whole mise-en-scene (characterization, lighting, setting, costume, etc.) contributes to the unfolding of the story (Bordwell 2004; Phillips 2000). The role an actor plays is also significant in that he/she contributes significantly to the mise-en-scene of the film. Actors convey meaning to their characters through physical appearance, movement, as well as through the words they speak and how they speak. Linguistic variation, by way of dialect or register, is an integral part of this characterization process and also a complex feature that is sometimes very hard to preserve in the translation. Several constraints are observed, especially in the case of subtitling, in terms of the number of strategies that can be adopted (e.g. Rosa 2004; Toury 1995). On the other hand, part of the meaning construction is accomplished through the non-verbal channels of the film, or through different forms of interaction between text (subtitles) and image. I here propose a pilot study of a small excerpt from the Gone with the Wind (1939) film subtitling for RTP (public television channel), TVI (private television channel), VHS and the Internet, which will look for translational regularities and compare the results with a previous national case study where the translation of Cockney was analyzed in two film adaptations of George Bernard Shaw's Pygmalion (Rosa 1999, 2001). ${ }^{1}$ 


\section{Audiovisual Translation}

In today's era of global communication and audiovisual media, translation is an essential means for allowing a successful flow of communication amongst diverse cultures and diverse languages. Since audiovisual translation is a very specific text type, a brief definition may be in order. Carvalho (2005) defines AVT as a combination of practices that mainly involve oral and written translation of programs and films of diverse natures and formats, which are subsequently exhibited or broadcast in diverse formats. Whenever a particular film or program is subsequently distributed in one of these formats, a new translation is normally created so as to meet the established media-norms and the specific target viewer.

Every translation in AVT, be it for subtitling, dubbing or voice-over, must consider the target audience, the established translational norms, the audiovisual medium and the technical implications involved. Hence, in AVT, as occurs with literary translation, the norms and regularities of the target culture must be considered. The notion of Polysystem Theory, put forth by Itamar Even-Zohar (1990), may be advantageous in visualizing where the act of audiovisual translating is situated within the greater Cultural Polysystem. Even-Zohar proposed the idea of a literary multiple system for the analysis of a translated literary piece. The same theory may be transposed to AVT, given that the same cultural polysystem not only incorporates both the audiovisual and literary polysystems, but also other subsystems in some of which translation is prominent.

Among the different AVT practices, subtitling for films is the main point of focus in this study. Subtitling is the most common choice of translation in Portugal and in other small European countries. This preference is generally associated with a long tradition in subtitling, lower expenses compared to dubbing, as well as with the idea of political correctness, due to the fact that the source text (ST) always remains accessible to the viewer (Danan 1991).

As a result of the ST and the target text (TT) being simultaneously accessible, the process of subtitling is usually defined as both "interlingual and intersemiotic translation" or as "diagonal translation". The former designations, used within the framework of Roman Jakobson (1959: 233), refer to a process that involves encountering a correspondence between source language and target language, but also the shift from a mainly verbal oral sign to a verbal visual sign. Henrik Gottlieb (1992), on the other hand, classifies subtitling as "diagonal translation", referring to the fact that the ST, despite its polysemiotic nature, is mostly associated with the auditory channel, whereas subtitles are linked with the visual channel.

As previously mentioned, the multimedia nature of the ST, including audible and visible gestures and the whole mise-en-scene in films, is essential for interpreting, not only what is said by characters, but also how it is 
said. In some cases these gestures may have the same meaning in ST and TT, but in others, they may be interpreted differently. In the latter case, it is even more important to focus on the non-verbal signs when they are essential to interpret the verbal signs, especially if they contradict each other. Moreover, the fact that the target viewers, too, can make use of both the visual information and the verbal information given in the subtitling must be taken into account.

In addition to the above aspects, there are several important technical constraints to be taken into account when subtitling, i.e.: space (maximum of two lines and limited number of characters per line) and time (duration of exposure), which lead to the reduction of the ST. The purpose of subtitles is to support the viewers in their understanding of the film, and therefore, they appear in synchrony with the audiovisual text and do not attract attention to themselves. As O'Connell writes, "subtitling is a process of visual supplementation" (1998:66).

\section{Linguistic Variation}

Linguistic variation is a feature that characterizes and codifies a speaker's/character's profile. According to Hatim and Mason (1990), a speaker's pronunciation (phonetic and phonological features) or dialect (morphological, syntactic and lexical features) encodes time and the geographical and social space to which he/she belongs.

When a specific character speaks a substandard variety, the subtitler's concern is to find a correspondence between the ST language variety and the TT language variety. On some occasions, it is very hard to preserve dialectal speech with its characteristic features, because there is no equivalent between the regional, socio-cultural or historical dialect/accent (Tomešová 1998). Many translators try to avoid this translation problem by rewriting the dialect into neutral standard language, irrespective of the function dialect has in the text. The unwillingness to cope with the translation of dialect is very often explained by the risk of creating an artificial language equivalent, which could spoil the effect of the whole text. More often than not in subtitles phonetic, morphological and syntactic shifts are avoided or omitted, or, in some cases, lexicalized (Rosa 2001). In general, the tendency is one of normalization where:

the representation of spoken language in the source text is adjusted towards the norms of written prose [therefore] creating a text which is more readable, more idiomatic, more familiar and more coherently organized than the original. (Laviosa-Braithwaite 1998: 290)

One possible explanation for a normalization strategy, especially in subtitling, is the instrumental role that the Portuguese written standard subtitles play in the promotion of literacy. An approach where the aim is to promote 
literacy may be the result of the following considerations: it may be associated with the lack of knowledge concerning language variation among translators; therefore, by adopting a standard written translation this will not only save the translator time, but also increase their speed in translating. In addition to promoting literacy, standard written subtitles contribute to the reading speed of viewers which is further developed because of the norm. ${ }^{2}$ The use of the Portuguese written standard in subtitles, therefore, contributes to both a more efficient reading experience for the viewer, as well as to the promotion of linguistic proficiency.

\subsection{Strategies for translating linguistic variation}

After analyzing the notion of AVT, the specific implications of subtitling, and linguistic variation, it is also important to devote some attention to situations in which these difficulties arise together. Under these circumstances, the dilemma of the translator is that of whether to follow the prestigious center of the Target Culture (TC) - preference for standard written Portuguese - or to recreate a relevant substandard dialect/accent in the Target Language. The latter alternative requires a decision of which Target Language dialect best depicts the ST, always bearing in mind regional and sociocultural features, the social implications of that decision and also how this non-standard form (or the standard one, for that matter) might interact with the character visibly present on screen.

As a result, two types of strategies have been considered applicable. The "Law of growing standardization" put forth by Gideon Toury (1995) and the "Centralizing or decentralizing pragmatic strategy of the Target Text" put forth by Alexandra Rosa (2004).

Toury (1995) aims to identify norms that will allow probabilistic laws of translation to be formulated and consequently, universals of translation. One of the laws presented by Toury is the "Law of growing standardization", in which the textual relationships established in the ST are usually modified in the TT, so as to adhere to the TC's repertoire. As a result, there is a process of standardization and loss of variation, because the ST is adapted to the norms of the TC. In other words, as Toury writes,

in translation, source-text textemes tend to be converted into targetlanguage (or target-culture) repertoremes. (...) Textual relations obtained in the original are often modified, sometimes to the point of being totally ignored, in favour of [more] habitual options offered by a target repertoire. (Toury 1995:268)

Rosa, on the other hand, introduces two types of translation strategies (2004: 342), the "centralizing and decentralizing pragmatic strategies of the Target Text" (also referred to as the Ptolemaic and Galileic strategies), with reference to the recreation or not, of a substandard linguistic variety. When the substandard of the source language is translated into the standard varie- 
ty of the target language, there is a centralizing strategy (clearly associated with Toury's "Law of growing standardization"). To be more precise, this strategy is predominantly characterized by the decision to shift the negative socio-semiotic value into a positive value or to simply omit the units encoding negative socio-semiotic value. In contrast, when the translator translates the substandard variety into an equivalent variety in the target language, there is a decentralizing strategy. In other words, the choices made during the translation process generally reveal the maintenance of the negative socio-semiotic value, the shift of the positive socio-semiotic value to negative value or simply the exclusion of units encoding positive socio-semiotic value. $^{3}$

\section{Case Study}

The text considered in this analysis is the film Gone with the Wind directed by Victor Flemming (1939) and the translation and subtitling for four different media: professional subtitles for the Portuguese public television channel (RTP), a private television channel (TVI) and VHS, and subtitles created by fans available on the Internet ${ }^{4}$ (www.opensubtitles.org).

The main purpose of this analysis is to determine whether the substandard linguistic variation present in the source language is transposed onto the subtitles, particularly in the speech of Mammy, an AfricanAmerican slave from the south of the United States of America. During the American Civil War in the nineteenth century, the English spoken amongst slaves shared influences from Creole and several dialects spoken by white people from the southern states. Thus, African-Americans spoke dialect with both a regional and sociocultural pronunciation, which has developed into what is now known as African American Vernacular English (AAVE) (Wolfram \& Schilling-Estes 1998 and Mufwene et al. 1998), with its own particular features. Some of the features heard in the following brief scene ${ }^{5}$ from the film include:

Morphological and Syntactic aspects

- $\quad$ Past tense absence.

e.g. "When Dr. Meade say her neck broke."

"... grabbed his gun and run out there and shoot that poor pony."

- Multiple negation.

e.g. "I ain't never seen no man set such store on any child."

"Miss Scarlett ain't never cared nothing about Miss Bonnie."

- The leveling of the verb "to be" in the first person singular in the present tense to "is".

e.g. "I sure is glad you's come."

- Perfective "done".

e.g. "This here's done broke her heart."

"He done lost his mind these last couple of days." 
- Regularization of reflexive forms by analogy with other possessive pronouns.

e.g. "I think he gonna shoot hisself."

Aspects of an oral variety

e.g. "gotta" "gonna"
"yes'm"

Bearing in mind these examples of AAVE, it will be worthwhile observing whether Mammy's speech is also rendered as a substandard variety in the different Portuguese subtitles. If so, will the chosen dialect and pronunciation reflect the regional and sociocultural values of slaves in the ST? Let us observe the subtitles from the corpus.

In the subtitles for the public television channel RTP, the translator chose not to transpose the substandard variety into the target language. This version has opted for the Portuguese written standard and therefore excludes all oral variety markers and substandard grammatical features present in Mammy's speech. It is worth mentioning that the forms of address such as 'Miss' and 'Mr' are not translated, but maintained in their original language since this is in accordance with one of the norms established by RTP. As a result, the subtitles aired on the public television channel follow a strategy of centralization. RTP, as a public entity, adheres to the values of the written standard, since it is this standard that occupies the prestigious center of the system. This process of normalization was also noted in a previous case study which analyzed the translation of the Cockney dialect for RTP in the film adaptation of Pygmalion (Rosa 1999). In addition, this approach confirms Veiga's study (2006) concerning the identification of subtitling as a pedagogical instrument that promotes literacy.

Contrary to the results in RTP, the subtitles for the private television channel TVI follow a strategy of decentralization. In Table 1 a small selection of examples may be observed. The strategies adopted make Mammy's speech and her character as a whole seem realistic in terms of the "southern African slave woman way of life", even if this meant not following the norms of the prestigious center. The effort to decentralize is patent in the spelling which marks a substandard accent by using representations such as "chamê" (modification of the spelling by changing the standard dithong [ei] into the monothong [e]), "podêe" and "doutô." (in which both the $<r>$ at the end of words are not written nor pronounced), and "nêgo" and "Minina" (both associated with vowel pronunciation). The text is also decentralized in terms of pronunciation and this can be seen in the effort to mark certain features of oral discourse by resorting to ellipsis (e.g. "'tava", "qu'enterro", "p'ra"), as is also observed in AAVE (e.g. "mornin"” and "yes'm"). Decentralization is furthermore observed in morphological and syntactical terms, as can be perceived in the lack of concord in number (e.g. "neste último dias"), the lack of contraction in preposition and article (e.g. "pegou em espingarda"), the substandard choice of personal pronouns (e.g. "deu força 
a ela", "mim cá pensou") and the lack of an article ("pô _ minha menina"). Decentralization is marked in lexical terms too, as the translator resorts to informal and low socio-cultural words and expressions such as, "Sinhô do Céu", "coração despedaçado", "deixa ralada" and "garrano".

Table 1: TVI subtitle analysis

\begin{tabular}{|c|c|l|}
\hline TVI subtitles & Standard Portuguese & \multicolumn{1}{|c|}{ Shifts } \\
\hline "chamê" & "chamei" & Pronunciation - [ei] > [e] \\
\hline "doutô" & "doutor" & $\begin{array}{l}\text { Pronunciation - missing <r> } \\
\text { at the end }\end{array}$ \\
\hline "Minina" & "negro" & $\begin{array}{l}\text { Pronunciation - vowel, con- } \\
\text { sonant }\end{array}$ \\
\hline $\begin{array}{c}\text { "p'ra"/"qu'enterro" } \\
\text { "tava" }\end{array}$ & "para" / "que enterro" & Pronunciation - vowel \\
\hline "neste último dias" & "nestes últimos dias" & $\begin{array}{l}\text { Inexistence of concord in } \\
\text { number }\end{array}$ \\
\hline $\begin{array}{c}\text { "pegou em espin- } \\
\text { garda" }\end{array}$ & "pegou na espingar- \\
da" & Lack of contraction \\
\hline "deu força a ela" & "deu-lhe força" & $\begin{array}{l}\text { Subject for object - personal } \\
\text { pronoun }\end{array}$ \\
\hline "mim cá pensou" & "eu cá pensei" & $\begin{array}{l}\text { Object for subject - personal } \\
\text { pronoun }\end{array}$ \\
\hline "pôo _ minha meni- \\
na"
\end{tabular}

After careful analysis we may conclude that the choice made was to translate the AAVE variety in the ST into the spoken substandard variety of an Afro-negro dialect from Brazil (Castro 1991, Cunha \& Cintra 1985, Elia 2003,). Some of the vernacular features of the substandard variety include: phonology (e.g. dropping of $/ \mathrm{l} /$ and $/ \mathrm{r} /$ at the end of words) and morphosyntactic features (e.g. use of the objective case of the first person personal pronoun as subject -"mim", use of the subjective case of the third person personal pronoun as direct object -"ele/ela", lack of concord in number, etc.).

Considering that the Portuguese public is exposed to Brazilian soaps on a daily basis and that the theme of slavery is frequently depicted in them (examples are Escrava Isaura and Gabriela Cravo e Canela), the average Portuguese television viewer is able to associate the written subtitles with the substandard variety traditionally depicting slaves in those soaps. This transposition of dialect and pronunciation into the TT is important for viewers who do not understand English. Not only the mise-en-scène of a film, but also the language it uses, determine how its fictional events are depicted and suggest given interpretations. Indeed, not only is the role of language with its socio-cultural, regional and temporal factors of crucial importance, but it also interacts with the mise-en-scène, in this case, creat- 
ing a more harmonious whole. A neutral, standardized subtitled version consequently limits the amount of information made available to the viewer

Focusing now on the subtitles for video cassette, we find that these are very similar to those of RTP, however on VHS the forms of address are translated (Menina for "Miss" and Senhor for "Mr."). There are, however, slight differences concerning the division of the subtitles and different translations in two cases:

Table 2: RTP and VHS subtitle differences

\begin{tabular}{|c|c|}
\hline$R T P$ & $V H S$ \\
\hline $\begin{array}{l}\text { "... num lugar escuro, quando ela } \\
\text { tem medo." } \\
\text { [... in a dark place, when she is } \\
\text { scared.] }\end{array}$ & $\begin{array}{l}\text { "... num lugar escuro, tendo ela } \\
\text { medo." } \\
\text { [... in a dark place, being that she is } \\
\text { scared.] }\end{array}$ \\
\hline $\begin{array}{l}\text { "Mr. Rhett sempre considerou muito } \\
\text { a sua opinião." } \\
\text { [Mr. Rhett always greatly consi- } \\
\text { dered your opinion.] }\end{array}$ & $\begin{array}{l}\text { "O Sr. Rhett sempre respeitou muito } \\
\text { a sua opinião." } \\
\text { [Mr. Rhett always greatly respected } \\
\text { your opinion.] }\end{array}$ \\
\hline
\end{tabular}

The same is the case with the two versions of subtitles created by anonymous translators and downloaded from the Internet site Opensubtitles. Considering that the Internet is a liberal and anonymous market for fansubbing, one might think it would be a space for greater freedom and creativity. According to Cintas and Sánchez (2006) this new form of subtitling is made by fans for fans and lies at the margins of the legal market imperatives; thus, they are generally characterized as being more creative and individualistic than traditional subtitles in other media (television, cinema or DVD). However, in this particular case, what was found was that people took advantage of subtitles already circulating on the open market. Both versions were posted by two different individuals with nicknames (PN Boy and DJJorgito) on two different dates (2003 and 2005). Contrary to what one would expect, these two versions from the Internet besides being identical, are also practically faithful copies of the subtitles on VHS, only differing in the division of the subtitles. One explanation for this practice may be that Gone with the Wind is a classic film with many translations available and fans do not see the need to create new subtitles. If it were a recent film or television program, the same tendency would most likely not be observed.

Summarizing, RTP, VHS and Internet subtitles follow a strategy of centralization, and it is only in the subtitles for the private television channel TVI that a strategy of decentralization can be discerned. What is more, a similar strategy of decentralization, was also observed in a previous case study analyzing the Cockney dialect of Eliza in the film adaptation of Pygmalion (Rosa 1999) aired on another Portuguese private television channel (SIC). In both films, the translator chose to maintain a substandard linguistic variation and informal register. 


\section{Conclusion}

After investigating Mammy's speech in the subtitles for diverse Portuguese media, it can be concluded that:

- $\quad$ RTP, as well as VHS and Internet subtitles, follow a strategy of centralization in terms of register and regional and sociocultural variety. The textual relations present in the ST were standardized so as to favor the central target repertoire, the written standard.

- $\quad$ TVI, on the contrary, follows a strategy of decentralization in terms of sociocultural variety and register, translating the substandard variety spoken by Mammy into an 'equivalent' variety in the target language. The conclusions observed in the television subtitling of Gone with the Wind for TVI, therefore, corroborate the findings of the previous study by Rosa (1999).

These two case studies of the Portuguese panorama point towards a decentralizing tendency in translations for private television channels, while the public channel adopts a strategy of centralization/normalization, so as to consciously promote the use of the Portuguese written standard. One reason for this type of practice may have to do with the fact that RTP is a public service channel with its own translation department, where the translators receive formal training; in contrast, private channels hire private translation companies where freelance translators work at home and clearly have more freedom for creativity in translation.

Even though the corpus of these two studies is very restricted, questions may be put forth so as to be analyzed in further research.

- To what extent is the translation of substandard linguistic varieties into a non-equivalent variety in the Target Language beneficial or not in grasping the true meaning of the character?

- $\quad$ Should there be a clear breach between strategies adapted by public and private television channels?

- Even though the written standard is traditionally the center of prestige in Portugal, is the decentralizing strategy a tendency that is gaining ground in Portugal and how is it being accepted by viewers?

Addressing these questions and many others is essential to understanding the tendencies adopted, the norms followed by translators, and the consequences they may have for the way in which the film is appreciated by its viewers. Furthermore, privatization of general television channels and growing competition with cable/satellite channels may also have consequences for the attitudes and strategies adopted by translators. However, these issues and many others will have to be dealt with in subsequent studies. 


\section{Bibliography}

Bordwell, David \& Kristin Thompson (2004). Film Art. An Introduction (7th ed.). New York: McGraw Hill.

Carvalho, Carolina Alfaro de (2005). A Tradução para Legendas: dos polissistemas à singularidade do tradutor. M.A. dissertation. Pontifícia Universidade Católica do Rio de Janeiro.

Castro, Ivo (1991). Curso de História da Língua Portuguesa. Lisboa: Universidade Aberta.

Cintas, Jorge Díaz (2003). Teoría y Práctica de la Subtitulación: Inglés - Español. Barcelona: Editorial Ariel.

Cintas, Jorge Díaz \& Pablo Muñoz Sánchez (2006). "Fansubs: audiovisual translation in an amateur environment". The Journal of Specialised Translation 6 (July), 37-52. http://www.jostrans.org/issue06/art_diaz_munoz.pdf (consulted 23.08.08).

Cunha, Celso \& Luís Lindley Cintra (1984). Nova Gramática do Português Contemporâneo. Lisboa: Edições João Sá da Costa.

Danan, Martine (1991). "Dubbing as an expression of Nationalism". Meta 36 (4), 606-614. http://id.erudit.org/iderudit/002446ar (consulted 04.09.08).

Elia, Sílvio (2003). Fundamentos Histórico Lingüisticos do Português do Brasil. Rio de Janeiro: Editora Lucerna

Even-Zohar, Itamar (1990). "Polysystems Studies". Poetics Today 11 (1), 27-44.

Gottlieb, Henrik (1992). "Subtitling - a new university discipline". C. Dollerup \& A. Loddegaard (eds). Teaching Translation and Interpreting. Amsterdam/Philadelphia: John Benjamins.

Hatim, Basil \& Ian Mason (1990). Discourse and the Translator. London/New York: Longman.

Jakobson, Roman (1959). "On Linguistic Aspects of Translation”. R.A Brower (ed.). On Translation. Cambridge: Harvard University Press, 144-151.

Laviosa-Braithwaite, Sara (1998). "Universals of Translation". M. Baker (ed.). Routledge Encyclopedia of Translation Studies. London/New York: Routledge, 288-291.

Mufwene, Salikoko, John Rickford, Guy Bailey \& John Baugh (eds.) (1998). AfricanAmerican English: Structure, History and Use. New York: Routledge.

O’Connel, Eithne (1998). "Choices and Constraints in Screen Translations". L. Bowker, M. Cronin, D. Kenny \& J. Pearson (eds). Unity in Diversity? Current Trends in Translation Studies.. Manchester: St. Jerome Publishing, 65-71.

Philips, Patrick. 2000. Understanding Film Texts. Meaning and Experience. London: British Film Institute.

Rosa, Alexandra Assis (1999). "The Centre and the Edges. Linguistic Variation and Subtitling Pygmalion into Portuguese". J. Vandaele (ed.). Translation and the (Re)Location of Meaning. Selected Papers of the CETRA Research Seminars in Translation Studies, 1994-1996. Leuven: CETRA Publications, 317-338.

Rosa, Alexandra Assis (2001). "Features of oral and written communication in subtitling." In: (Multi) Media Translation: Concepts, Practices and Research. Yves Gambier \& Henrik Gottlieb (Eds.). Amsterdam/Philadelphia: John Benjamins Publishing Company. 213-221.

Rosa, Alexandra Assis (2004). Tradução, poder e ideologia : retórica interpessoal no diálogo narrativo dickensiano em português : 1950-1999. $\mathrm{PhD}$ thesis. University of Lisbon, Faculty of Letters.

Tomešová, Ivana (1998). "Translation of dialect in Kipling's Stalky \& Co." Online at: http://www.phil.muni.cz/ jirka/children/children1/kipling/tomesova_stalky.rtf (consulted 23.08.08).

Toury, Gideon (1995). Descriptive Translation Studies and Beyond. Amsterdam/Philadelphia: John Benjamins Publishing Company.

Veiga, Maria José Alves (2006). "Subtitling Reading Practices". J. Ferreira Duarte, A. Assis Rosa \& T. Seruya (eds). Translation Studies at the Interface of Disciplines. Amsterdam/Philadelphia: John Benjamins Publishing Company, 161-168.

Wolfram, Walt \& Schilling-Estes, Natalie (1998). American English. Malden/Oxford: Blackwell Publishers. 331-344. 


\title{
Filmography
}

\author{
Subtitled versions of Gone with the Wind (1939) Producer David O. Selznick: \\ Broadcast by RTP - Public Television Channel \\ Translated by: Maria Auta de Barros and Subtitled by: Verónica Carizo \\ Broadcasted: 18/10/87; 23/09/91; 19/12/93; 08/01/98; 03/06/99; 25/12/99; 17/07/04; \\ 01/01/05 \\ Broadcast by TVI - Private Television Channel \\ Translated and subtitled by: Isabel Monteiro / Ideias e Letras \\ Broadcasted: 20/12/02 \\ VHS - video cassette \\ Translated and subtitled by: Carmen Cabrita (2002) \\ Internet - www.opensubtitles.org (January 28, 2007) \\ British English subtitles translated by: $\mathrm{rG}(05 / 12 / 2001)$ \\ European Portuguese subtitles translated by: PN Boy (24/10/2003) and DjJorgito \\ $(20 / 11 / 2005)$
}

${ }^{1}$ In this earlier study, two film adaptations of George Bernard Shaw's Pygmalion are analyzed, one aired on the public channel (RTP) and another on a different private channel (SIC). The results are the following: public television - strategy of centralization vs. private television - strategy of decentralization. In the case of Eliza's character in Pygmalion, the progress she makes from Cockney to correct English throughout the story is especially difficult to transpose into another language and particularly within the technical constraints of subtitling.

${ }^{2}$ In Portugal, for example, the reading habits of youngsters is considerably low, however, these spend several hours a day watching television, especially foreign subtitled programs. Maria José Veiga (2006) analyzed the television habits and opinions of 293 Portuguese students from a middle school. In her study she was able to conclude that students prefer subtitles and are aware of their importance as instruments that promote the Portuguese language. For instance, $44.7 \%$ of the students stated that subtitling helps to develop reading speed, $31.9 \%$ believe subtitles contribute to the general learning of the Portuguese language and $36.4 \%$ refer to subtitles as an instrument to help them express themselves better in Portuguese.

${ }^{3}$ The effect of both strategies in subtitles may be somewhat 'altered' by the presence of the character on screen, with his/her visual socio-semiotic value. However, at this point, taking such a consideration into account would lead us too far. Moreover, such visual socio-semiotic values may be hard to measure.

${ }^{4}$ Subtitles created by amateurs are denomianted as 'fansubs', a term initially designating a fanproduced, translated, subtitled version of a Japanese anime program. Fansubs share the same characteristics of professional subtitling, but they are known for being more daring in terms of translation and formal presentation.

${ }^{5}$ The scene chosen to analyze is towards the end of the film when Mammy opens the door to Miss Melanie, who has gone to visit Scarlett. The conversation analyzed takes place while both climb up the stairs to Scarlett's room, where she has locked herself since Bonnie's death.The examples cited in the article are solely some of those present in the conversation. Due to the limited space not all aspects can be approached in this analysis. 